\title{
A graphic reconstruction method of an average vine leaf
}

\author{
María-Carmen Martinez ${ }^{a^{*}}$, Serge Grenan ${ }^{\mathrm{b}}$ \\ ${ }^{a}$ Misión Biológica de Galicia (Consejo Superior de Investigaciones Científicas), Apartado de Correos 28, 36080 Pontevedra, Spain \\ b Établissement National Technique pour l'Amélioration de la Viticulture, Domaine de l'Espiguette, 30240 Le Grau du Roi, France
}

(Received 10 January 1998; accepted 25 May 1999)

\begin{abstract}
The description of vine varieties has been under consideration for many years. A parameter description enabling the best variety characterisation has been improved over the years. However, even though some results have been achieved, no method enables a rapid and clear visualisation of the leaf morphology of any vine variety. Here, we present an average leaf reconstitution method from measures carried out on a sample representative of the variety. On leaves divided into sectors, we measured the fundamental parameter of the angles and length as well as notations on the qualitative character. These measures are: tooth number and shape, sinus morphology and vein arrangement. Using this information, we established a method which allows step by step average leaf reconstitution. Of course, this method could be improved; nevertheless, it is a tool easy to obtain and to use by experimenters wishing to compare their statistical results with an accurate synthetic representation. The validity of our proposal is proven with the graphic representation of the average leaf of eight very well-known worldwide varieties, such as Cabernet-Sauvignon, Alicante Bouschet, Jerez, Muscat à petits grains and Chasselas Cioutat, and other very important varieties in the north-west of Spain and north of Portugal, such as the Albariño, Godello and Loureira varieties. In addition, data collected using this means could be the basis of computerisation of the method. (@ Inra/Elsevier, Paris.)
\end{abstract}

\section{ampelometry / average leaf / graphic reconstruction / Vitis}

Résumé - Méthode de reconstruction graphique d'une feuille de vigne. La description des cépages a fait l'objet d'études depuis les temps très anciens. La définition des paramètres permettant de caractériser au mieux les variétés s'est affinée au fil des années. Cependant malgré la multitude des travaux réalisés aucune méthode ne permet de visualiser rapidement et de façon claire la morphologie foliaire d'un cépage. Aussi nous proposons une méthode de reconstitution d'une feuille moyenne à partir de mesures effectuées sur un échantillon représentatif de la variété. Sur les feuilles divisées en secteurs, on réalise des mesures sur les paramètres fondamentaux de longueurs et d'angles mais aussi des notations sur les caractères qualitatifs: nombre et forme des dents, morphologie des sinus, et disposition des nervures. $\grave{A}$ l'aide de ces informations on établit une méthode qui permet de reconstituer pas à pas la feuille moyenne. Cette métho-

\section{Communicated by Gérard Guyot (Avignon, France)}

* Correspondence and reprints

csgpomcm@cesga.es 
de présente, évidemment, quelques imperfections mais elle constitue un outil facile à réaliser et à utiliser par l'expérimentateur qui souhaite confronter ses résultats statistiques avec une réprésentation synthétique la plus fidèle possible. Nous avons prouvé la validité de notre proposition avec la réprésentation graphique de la feuille moyenne de huit cépages, quelques uns d'entre eux très connus au niveau mondial comme Cabernet-Sauvignon, Alicante Bouschet, Jerez, Muscat à petits grains et Chasselas Cioutat, et d'autres originaires du nord-ouest de l'Espagne et du nord du Portugal comme Albariño, Godello et Loureira. De plus les données recueillies pourraient servir de base pour une informatisation de la méthode. (@ Inra/Elsevier, Paris.)

\section{ampélométrie / feuille moyenne / reconstruction graphique / Vitis}

\section{Introduction}

The word 'ampelography' was used for the first time in the 17 th century by Sachs [34] to designate the study of vine variety.

It was only from the 19th century onwards that works on this speciality could be found. One of those authors was Clemente [6], who published the first important book on ampelography, followed by an illustrated version [7].

Later, Goethe [17] focused his attention on the importance of angles produced by the main veins of the leaf, and highlighted the need for an international co-operation in ampelographic studies [34]. Ravaz [25] divided leaves into ten categories, according to angles produced by main veins, and established the foundations of modern ampelography, giving its actual importance to ampelometric measures. The reference book Ampelography by Viala and Vermorel [34] appeared at the beginning of the 20th century, compiling the whole knowledge of that time and developing aspects misunderstood up till then. This book presents a large amount of illustrations which represent the main varieties of vine.

More recently, Rodrigues focused on leaf morphology [26, 27], on the importance of the number of teeth in the Vitis genus hybrid differentiation [28], on leaf polymorphism, on ampelometry [29] and on vine leaf asymmetry [30]. He established a method on the representation of an average leaf [31].

Galet published a large selection of books [14-16] in which the description of vine varieties is broadly illustrated with drawings and photographs. He proposed the measurement of various organs taken at different moments of their vegetative cycle. He mainly used quantitative parameters, treated in a qualitative manner by establishing the vein length, angle and pubescence density classes. Berry, bunch and sex characteristics (which were up till then the bases of ampelographic descriptions) became complementary parameters that are only taken into account when leaves are really similar.

In the last few years, UPOV (International Union for the Protection of New Varieties of Plants), IBPGR (International Board for Plant Genetic Resources) and OIV (Office International de la Vigne et du Vin) experts established a definition of the necessary ampelographic characteristics for the Vitis genus varieties and for the identification of species [23].

Present-day studies focus on finding new parameters in order to differentiate varieties of vine precociously, quickly and efficiently. The use of ampelometry and image analysis associated with statistical analyses should lead to the creation of databases taking into account only the more discriminating leaf parameters.

Along these lines, we can mention the work conducted in France by Boursiquot et al. [1, 2], who introduced new computerised and statistical techniques, with the improvement of an ampelometric determination key. In Italy, Schneider and Zeppa [33] used a digitalisation table, and Costacurta and Zambon [9] presented a new computerised method which enables the reconstruction of an average leaf figure, and very recently Schneider [32], de Michelis et al. [10] and Costacurta et al. [8] presented studies on the different ampelographic tech- 
niques. In Germany, Dettweiler [11] proposed a list of the minimum descriptive characteristics. In Portugal, Carneiro and Lima [4] described different vine varieties using Rodrigues' method [31] and numerical taxonomy techniques, while Eiras-Dias [12] carried out studies on odontometry. In Spain, Cid-Alvarez et al. [5] presented an ampelometric determination key, and Martínez et al. [20] carried out studies on the variability of various parameters for ampelographic description [22].

Nevertheless, and in spite of all the work already carried out, no efficient method allowing a satisfactory description of various vine varieties has yet been found. Such a method would enable the comparison of results obtained in different places by different authors.

Taking as a starting point the study of the artificial variability achieved from the somaclones of Grenache N, we tried to identify the parameters that would allow us to differentiate the somaplants from the control plants in the field. The biometric study of the foliar characters $[18,19]$ showed that the component principal analysis was the analysis that provided more information concerning the parameters and the vines. This study showed that there was a mean year effect and soil effect on the foliar size. But apart from the year and the environment, some of the depth sinus parameters we established were enough to differentiate individuals with a significant degree of accuracy.

In view of the somaclonal variation established in this way at the foliar morphology level, we wanted to develop a graphic method to visualise as fast as possible the differences that appeared in the biometric study. The graphic representation of the leaf, established from the results of the statistical analysis, allowed us to evaluate in a synthetic way the variability within a variety and it also provided a highly realistic representation of the meaning of the statistical data in relation to the foliar morphology. We present in this paper the method of the graphic reconstruction of an average leaf. The validity of the method can be proved thanks to the graphic representation of the average leaf of eight varieties, some of them with a worldwide-known leaf morphology.

\section{Materials and methods}

\subsection{Plant material}

To apply the reconstitution method, we worked on eight vine varieties, some of them well-known worldwide, such as Alicante Bouschet, Cabernet-Sauvignon, Chasselas Cioutat, Jerez, Muscat à petits grains, and other varieties important in the north-west of Spain and north of Portugal, such as Albariño, Godello and Loureira.

The vines used for our study are from the collection at the Misión Biológica de Galicia (C.S.I.C.). Each genotype is represented by ten vines.

\subsection{Drawing materials and image capture}

In order to draw the leaf reconstitution, we need lead pencils and china ink fountain-pens with $0.2,0.4$ and 0.6 points. These drawings can be made on any type of paper.

We used a Scanner OmniMedia Scanner XRS 12CX and the image capture program PhotoFinish 2.0 to capture the image of each leaf of the sample and the average leaf drawing.

We used the image analysis program MIP 4 Advanced, MICRON to take the measurements on each leaf.

We used the Adobe illustrator 7.0 program to amplify, reduce and introduce the numbers on the drawing.

\subsection{Methods}

\subsubsection{Sampling}

Adult leaves were collected in August. The sample consisted of 11 leaves, situated at random, between the 8 th and 12 th node of a main shoot. For one of the ten plants of each variety we took two leaves, and one leaf for each of the other nine plants. Therefore, we had 11 leaves per variety.

Several studies $[3,11,13,23]$ have proved that ten leaves between the 8 th and the 12 th nodes of the shoot were enough to constitute a representative sample and that they would provide a reliable ampelographic description of a given variety. These authors argue that using this kind of sampling it is possible to obtain leaves with the weakest fluctuation caused by environmental conditions and it also permits the calculation of a repre- 
sentative average value. We took 11 leaves (instead of ten) per variety to make the calculation of the average value of the qualitative parameters easier. These 11 leaves were next pressed and placed in a herbarium before being analysed. The storage in herbarium fulfils several functions: 1) the material is kept in favourable conditions; 2) it can be conserved for a long time; 3 ) any author could repeat the measurements on the same leaves at any moment. The leaves measured for each variety are stored in the collection of herborised leaves in the Misión Biológica de Galicia (C.S.I.C.).

\subsubsection{Ampelometric parameters}

We scanned the 11 leaves of each variety with an OmniMedia Scanner XRS 12CX and the image capture program PhotoFinish 2.0. On each image we measured the vein length and the angles with an image analysis program (MIP 4 Advanced, MICRON).

The parameters are gauged on each leaf as shown in figure 1 (lines).

The position of the leaf [25] is such that its petiolar point as well as the lower sinuses are situated at the top, while the upper sinuses are at the bottom. This representation, in contrast with the old descriptions, is more consistent with what one can see in the vineyard.

The parameters used are the following:

$\mathrm{L}$ : linear distance between the petiolar point and the central vein end;

L1: linear distance between the petiolar point and the end of the first right (L1d) and left (L1g) lateral veins;

L2: linear distance between the petiolar point and the end of the second right (L2d) and left (L2g) lateral veins;

L3: linear distance between the starting point of the first secondary vein belonging to the second lateral vein and the end of the right (L3d) and left (L3d) secondary vein;

L5d: linear distance between the petiolar point and the starting point of $\mathrm{L} 3 \mathrm{~d}$;

L5g: linear distance between the petiolar point and the starting point of $\mathrm{L} 3 \mathrm{~g}$;

S1: linear distance between the petiolar point and the bottom (towards the petiolar point) of the right (S1d) and left (S1g) lateral upper sinuses;

S2: linear distance between the petiolar point and the bottom (towards the petiolar point) of the right ( $\mathrm{S} 1 \mathrm{~d}$ ) and left (S1g) lateral lower sinuses;

A: angle between the central vein and the first right lateral vein;

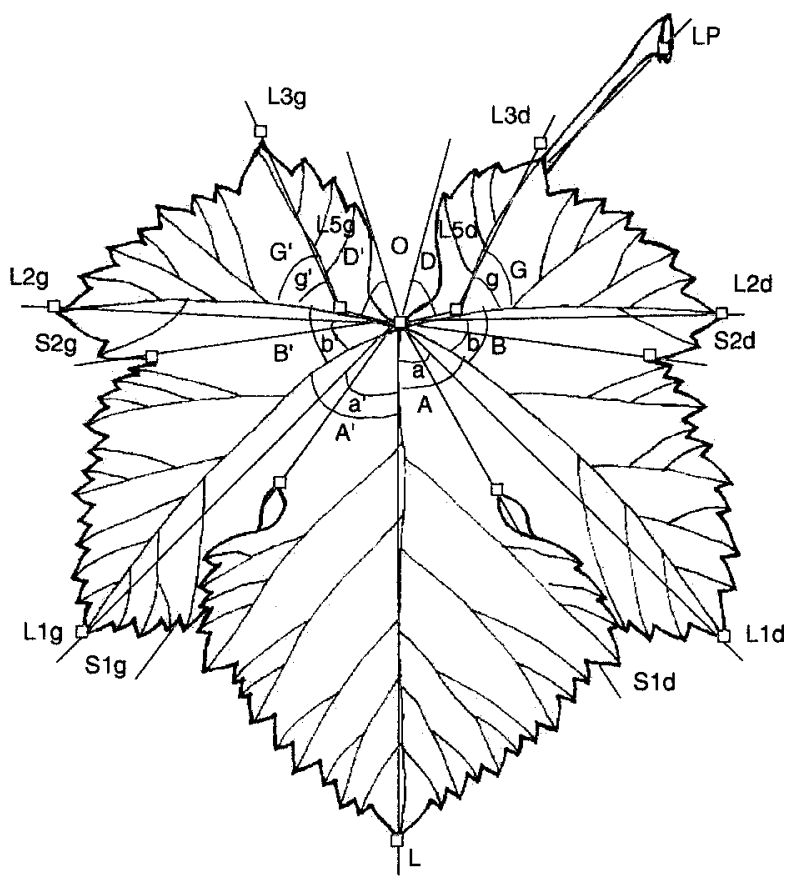

Figure 1. Quantitative parameter measures on each leaf.

A': angle between the central vein and the first left lateral vein;

a: angle between the central vein and L1d;

a': angle between the central vein and L1g;

$\mathrm{B}$ : angle between the first and the second right lateral veins;

$\mathrm{B}^{\prime}$ : angle between the first and the second left lateral veins;

b: angle between the first right lateral vein and L2d;

b': angle between the first left lateral vein and $\mathrm{L} 2 \mathrm{~g}$;

G: angle between the second right lateral vein and the first secondary vein of this;

G': angle between the second left lateral vein and the first secondary vein of this; L3d;

g: angle between the second right lateral vein and g': angle between the second left lateral vein and L3g;

D: angle between L5d and the tangent of the leaf right side from the petiolar point;

D': the angle between $\mathrm{L} 5 \mathrm{~g}$ and the tangent of the leaf left side from the petiolar point. 
After measuring the dry leaves, an average value is calculated on each parameter. These values (table $I$ ) will be used when reconstructing the average leaf architecture (figure $3 a$, steps $1-6$ and figure $3 b$, steps 7-12).

\subsubsection{Complementary notations}

\subsubsection{Notations on teeth}

From tooth size, three classes are defined [23]: small, medium and large.

According to the curvature observed on the tooth sides, four categories are defined [23]: ogival (two convex side, with a sharp mucron), hooked (one convex side and one concave side), angular (two rectilinear angle sides) and two concave sides. General leaf observation enables the association of the denture with one of the above-mentioned categories that are not limited.

To numerate teeth, following Rodrigues [30], we count teeth by sectors (table II). In each interval, a number is given to every tooth: Arabic numerals if the attached vein is a lower secondary one and Roman numerals if the attached vein is an upper secondary vein. If the vein of the tooth is a tertiary vein, the tooth is given the number of the previous tooth to which a letter is added (example: la, IIb) (figure 2).

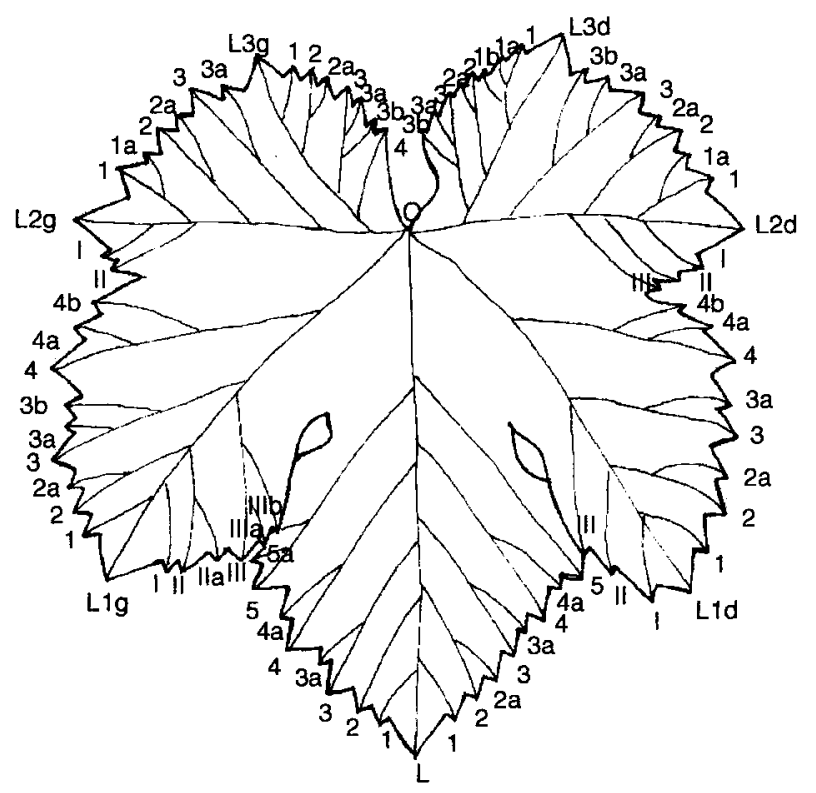

Figure 2. Numeration assigned to each tooth of the leaf depending on its position and its orientation from the main vein of each sector.
For each sector of the leaf perimeter, the size of the two-tooth categories is noted down according to its attachment to either main veins or secondary veins

\subsubsection{Sinus morphology}

The relevant information for lateral upper and lower sinuses is whether they are deep sinuses with parallel sides or not, and whether lobes are overlapping or not (table III) [23].

The same applies to the petiolar sinus, where both the shape and the degree of lobe opening are noted.

\subsubsection{Notations on veins}

The point where secondary veins split towards the right and left from the main veins has to be checked in order to note if this split occurs at the same level on the main vein, or if there is a gap between them (table III).

As to qualitative parameters, the one used in the average leaf is the one observed on at least six leaves out of the 11 that have been analysed. We used 11 leaves per variety instead of ten, to avoid the possibility of finding five leaves with a certain shape and the other five with a different shape, a fact which would make it difficult to choose the most appropriate to introduce in the average leaf reconstruction.

\section{Results}

\subsection{Reconstruction of an average leaf step by step}

The information gathered after the analysis of the eight varieties of leaves is compiled in tables $I-I I I$, together with any particular comment.

First we draw the leaf in pencil to be able to correct it during the process; but the definitive drawing is made in china ink.

To conclude, we should mention that both the notations on the different characteristics necessary to the leaf reconstruction, as well as the tracing of the leaf blade shape, are made sector by sector. Each sector has been defined by a leaf blade portion situated between two main veins. Therefore, a leaf can be divided into eight sectors: L-L1d, L1dL2d, L2d-L3d, L3d-O, O-L3g, L3g-L2g, L2g-L1g, $\mathrm{L} 1 \mathrm{~g}-\mathrm{L}$ and each of these sectors is independent. 


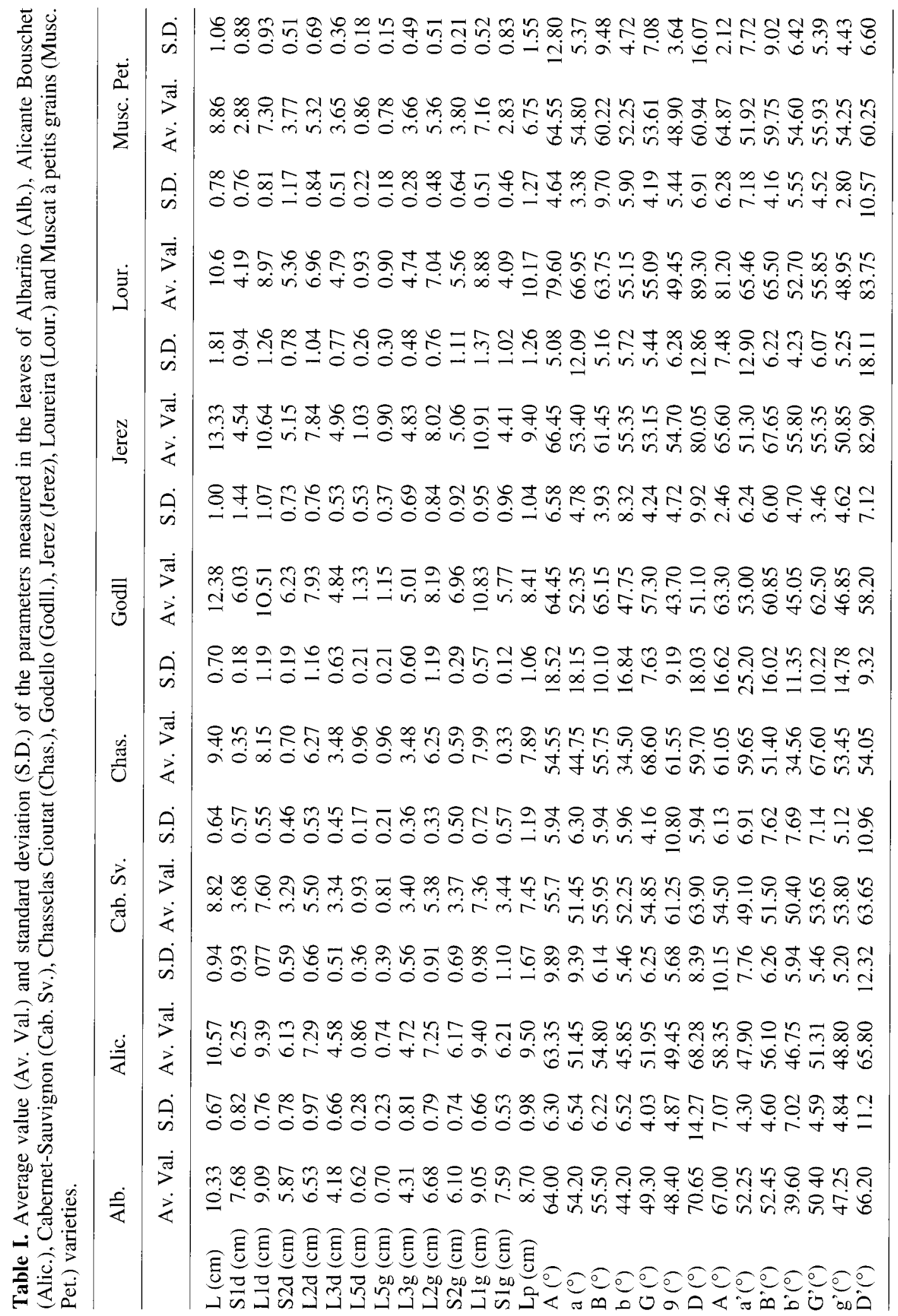




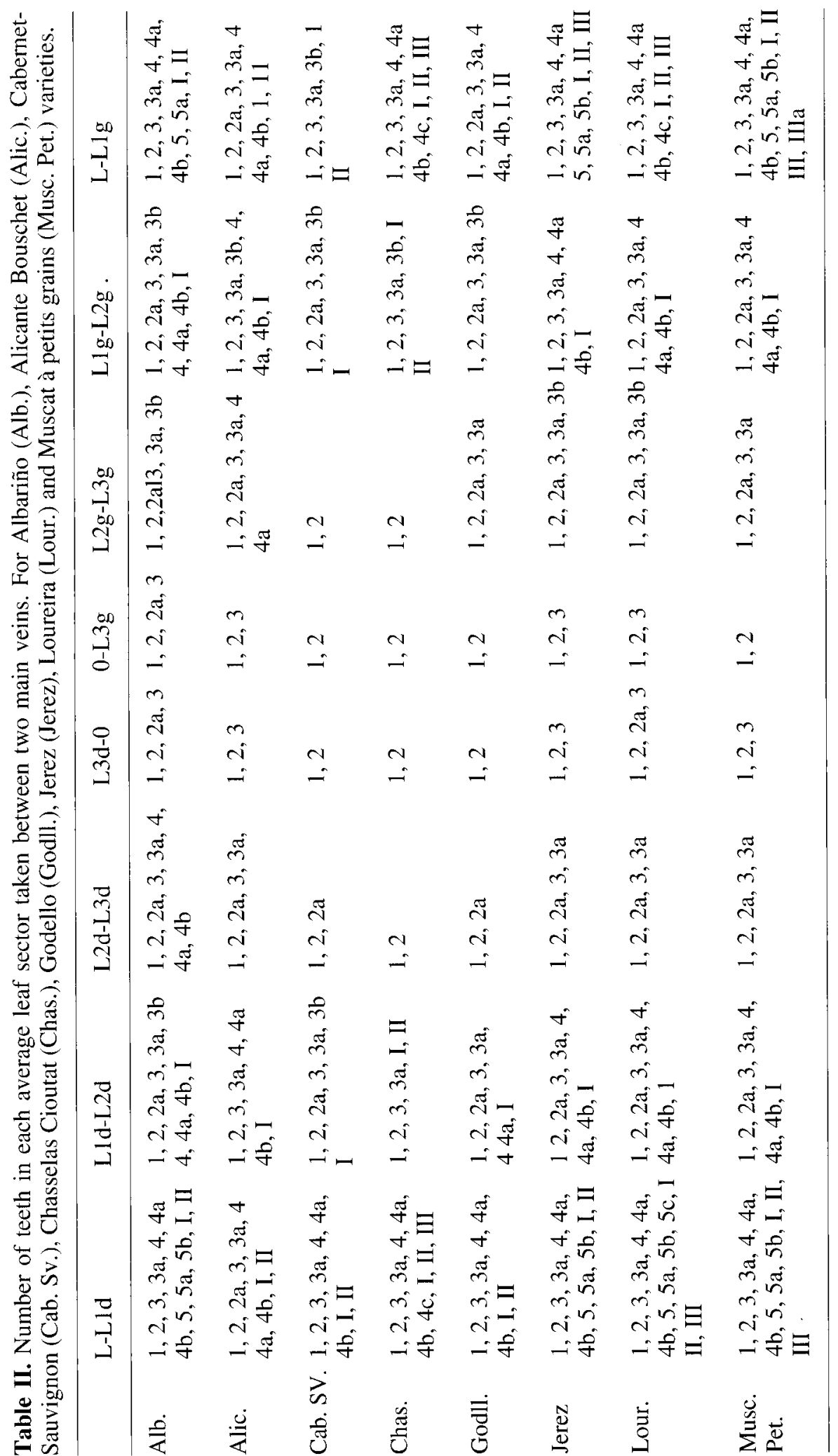




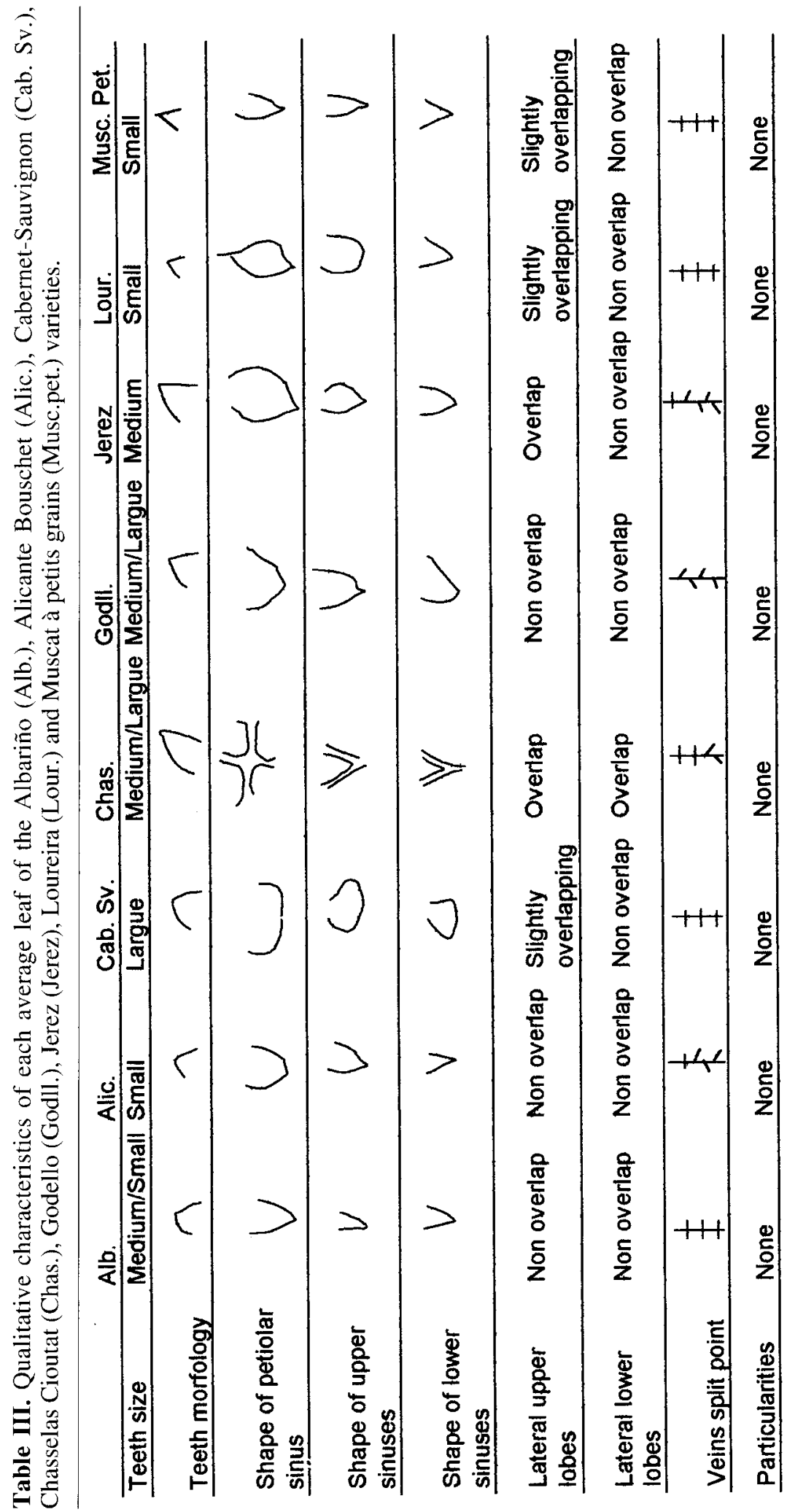



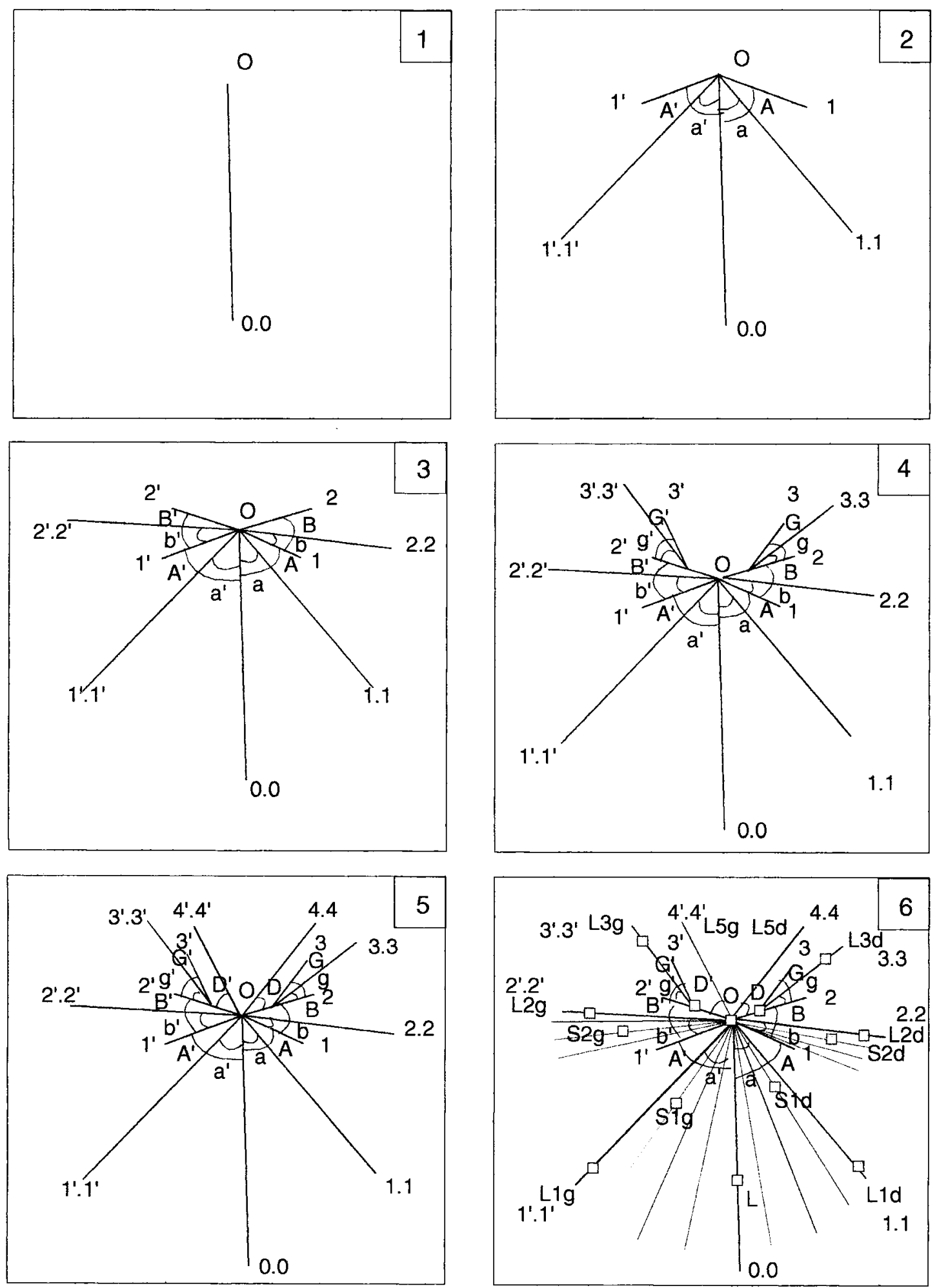

Figure 3. a) Steps 1-6 of the black and white average leaf reconstruction. 

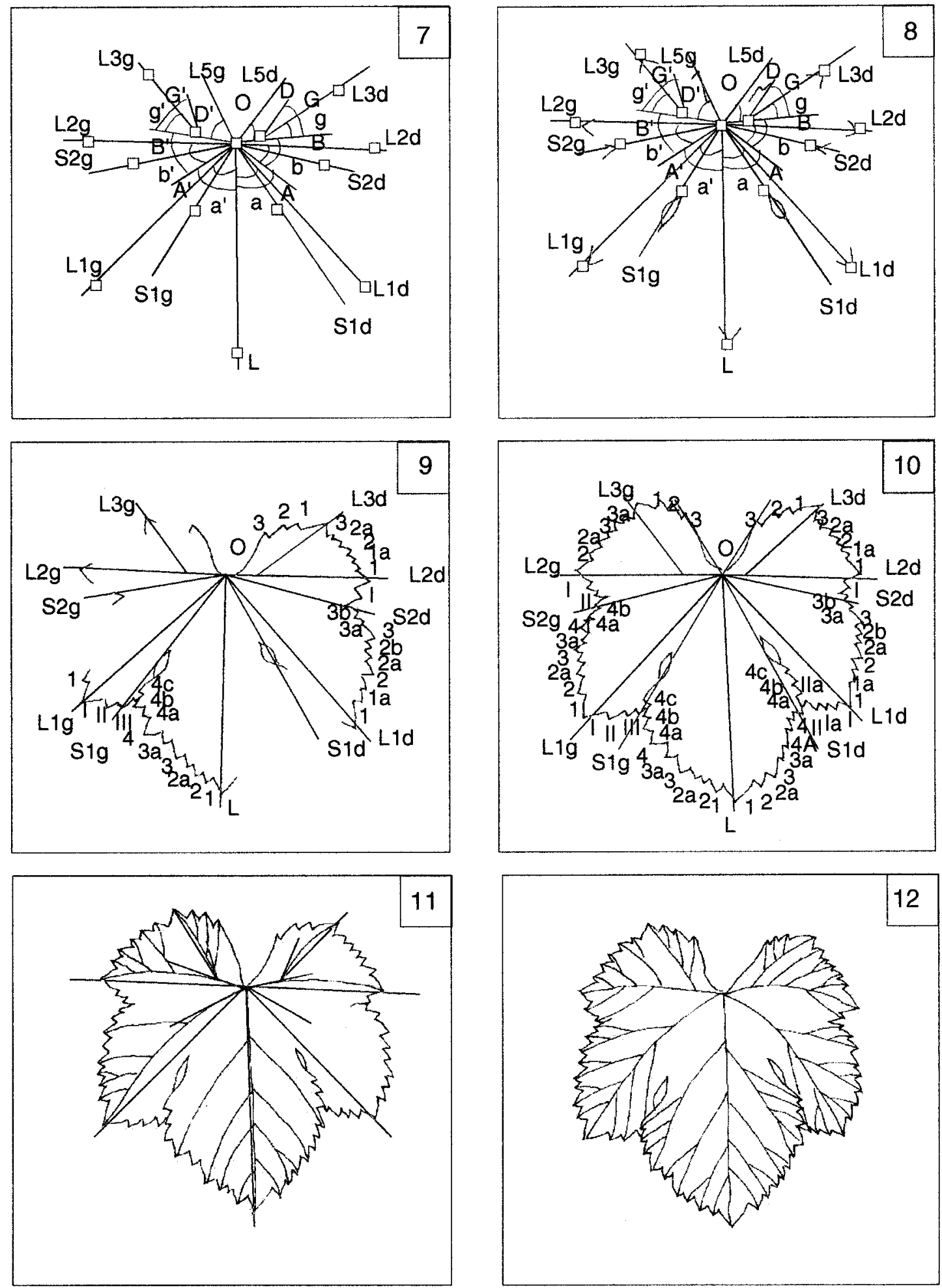

Figure 3. b) Steps 7-12 of the black and white average leaf reconstruction. 
All the different steps of the reconstruction process are shown in figure $3 a$ (steps 1-6) and figure $3 b$ (steps 7-12).

First, we have to locate the central point O, representing the petiolar point of the leaf. From this point, we draw a line towards the bottom of the sheet to represent the symmetry axis of the leaf (step 1).

From this axis, and taking the point $\mathrm{O}$ as the centre, angles a and a' have to be graphically represented by lines 1.1 and L'.l' (= LId and Llg), and the angles $A$ and $A$ ' by lines 1 and 1' (tangents to the veins) (step 2).

From lines 1 and 1 ', angles $b$ and $b$ ' have to be determined and graphically represented by lines 2.2 and $2^{\prime} .2^{\prime}$ (= $\mathrm{L} 2 \mathrm{~d}$ and $\mathrm{L} 2 \mathrm{~g}$ ), and the angles B and $B^{\prime}$ by lines 2 and 2 ' (tangents to the veins) (step 3).

On those last lines (2 and 2'), and starting from the petiolar point $(\mathrm{O})$, we marked the average length of L5d and L5g; at this point we placed the top of the $g, g^{\prime}, G, G^{\prime}$ angles and the starting point of the $3.3,3^{\prime} .3^{\prime}, 3$ and 3' lines, respectively (step 4).

Finally, from point $\mathrm{O}$ and on 2 and 2' lines, angles $\mathrm{D}$ and $\mathrm{D}^{\prime}$ have to be marked and represented by lines 4.4 and 4'.4' (step 5).

Once the angles are positioned, the tips of the main veins have to be marked on each of the corresponding lines previously drawn (step 6).

To position the lateral sinuses, angles a and a' have to be previously divided into approximately four equal angles (step 6). The base of the lateral upper sinuses $S 1 d$ and $S 1 g$ is situated on the line of the quarter closer to Lld and Llg. In the same way, the base of the lateral lower sinuses $\mathrm{S} 2 \mathrm{~d}$ and $\mathrm{S} 2 \mathrm{~g}$ is located in the line of the quarter closer to $\mathrm{L} 2 \mathrm{~d}$ and L2g (steps 6 and 7). Then, using table III, the shape of the base of the lateral sinuses and the shape of the associated teeth have to be drawn at the appropriate ends (step 8).

To draw the perimeter of the leaf, follow the directions in table $I I$ where the number of teeth per sector are mentioned. Table III also provides information regarding the possibility of lobes overlapping, the teeth morphology, etc. In this way, sector by sector, the perimeter of the leaf is reconstituted (step 9). For each independently reconstructed sector, one has to start with tooth 1 , then 2 , and the underlying tooth $2 \mathrm{a}$, going on to end up with teeth I, II, etc.

To improve the drawing, which was done using the Staedler Noris graphite pen, one can erase the intermediary lines, which were used to position different items and which are no longer valid now. Then, the perimeter may be drawn again using china ink (Staedler china ink pen 0.2, 0.4 and 0.6, step 10).

To finish the reconstitution of the leaf, the veins have to be drawn following the directions in table III. This step has to be started from the main veins to the secondary veins and from the tooth towards the main vein (step 11).

For the finishing touch, veins can be highlighted using china ink pens of different diameters $(0.2$, $0.4,0.6)$, taking into account that main veins are more prominent than secondary ones, and these last veins more than tertiary ones (step 12, figure $3 b$ ).

Another option that we recommend in order to have an accurate final drawing consists in drawing the leaf on another sheet of paper. Starting from the leaf in step 10 (figure $3 b$ ), the outline of the drawing is blackened on the reverse side of the sheet with the help of a bar of pure graphite (Faber Castell 290 HB). To obtain the final leaf on the new sheet of paper, the outline of the reconstructed leaf (and eventually the veins) is traced at the top of the paper with the help of a sharp object. To end up, china ink pens of different caliber are used.

Once we have the drawing on a clean paper, we scan it with the PhotoFinish 2.0 and then, using Adobe 7.0 we can amplify or reduce (depending on the need); then we write down the average values on each parameter, or simply store the image for future comparisons with other images.

\subsection{Applications}

Following the steps we have just explained, and taking into account the mean values of each para- 
meter (table I), the number of teeth (table II) and other qualitative characters related to leaf morphology (table $I I I$ ), we reconstructed the average leaf of the following varieties: Albariño (figure 4), Alicante Bouschet (figure 5), Cabernet-Sauvignon (figure 6), Chasselas Cioutat (figure 7), Godello (figure 8), Jerez (figure 9), Loureira (figure 10) and Muscat à petites grain (figure 11).

Finally, the different steps of reconstitution of the leaf, summarised in table $I V$, could set the bases for the elaboration of a program of form recognition adapted to ampelography.

\section{Discussion, conclusion}

Previous work concerning ampelography is the result of collecting minute observations joined to the experience acquired throughout their authors' lifetimes. The more representative works of art are illustrated ampelographies such as Clemente's [7] and Viala and Vermorel's [34], which are still a reference in the description of vine varieties.

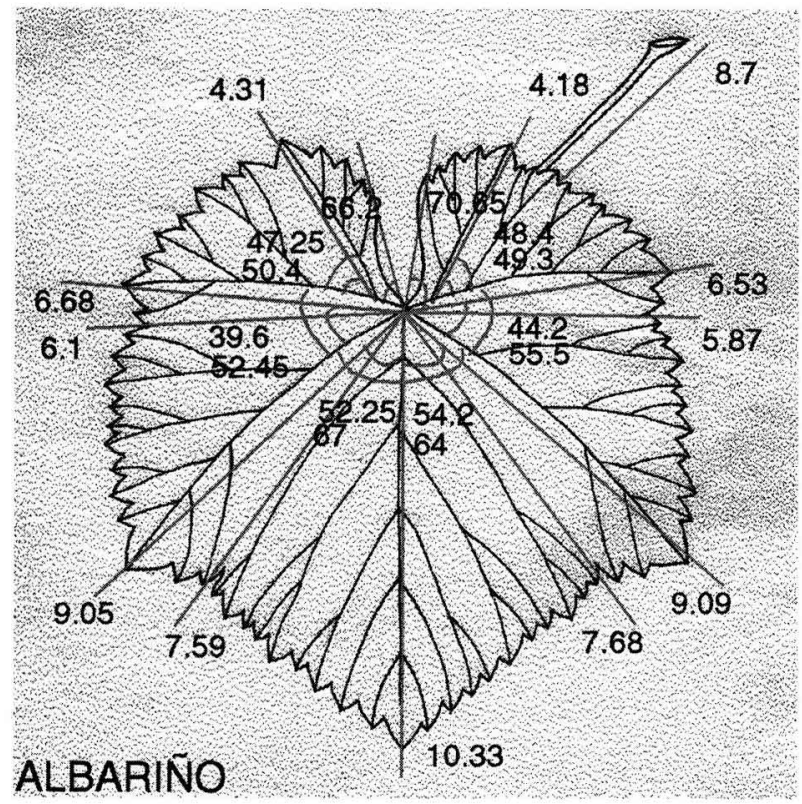

Figure 4. Average leaf of the Albariño variety (length in $\mathrm{cm}$, on the outside of the picture; angles in degrees, on the inside of the picture).

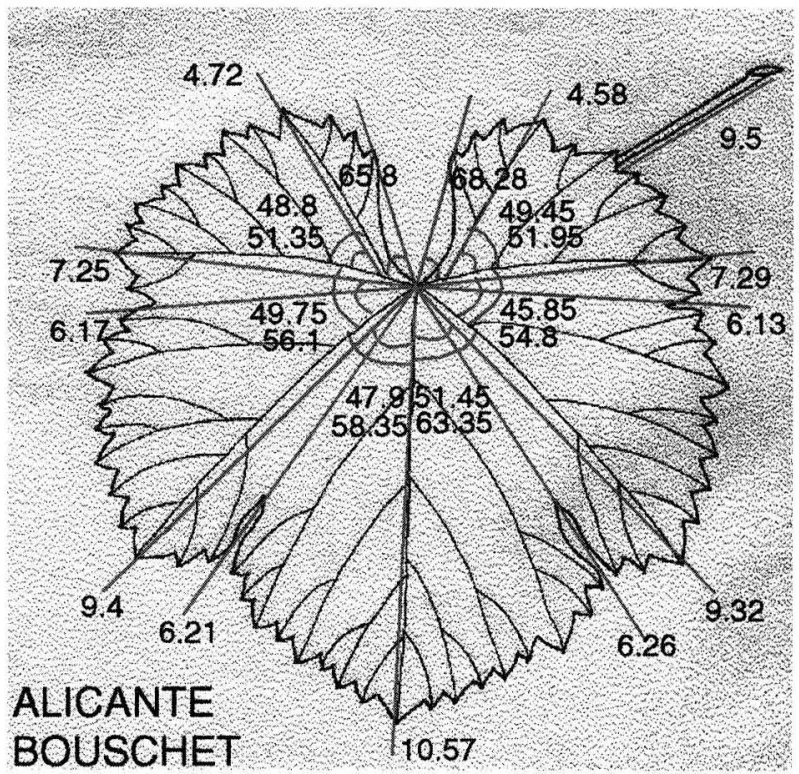

Figure 5. Average leaf of the Alicante Bouschet variety (length in $\mathrm{cm}$, on the outside of the picture; angles in degrees, on the inside of the picture).

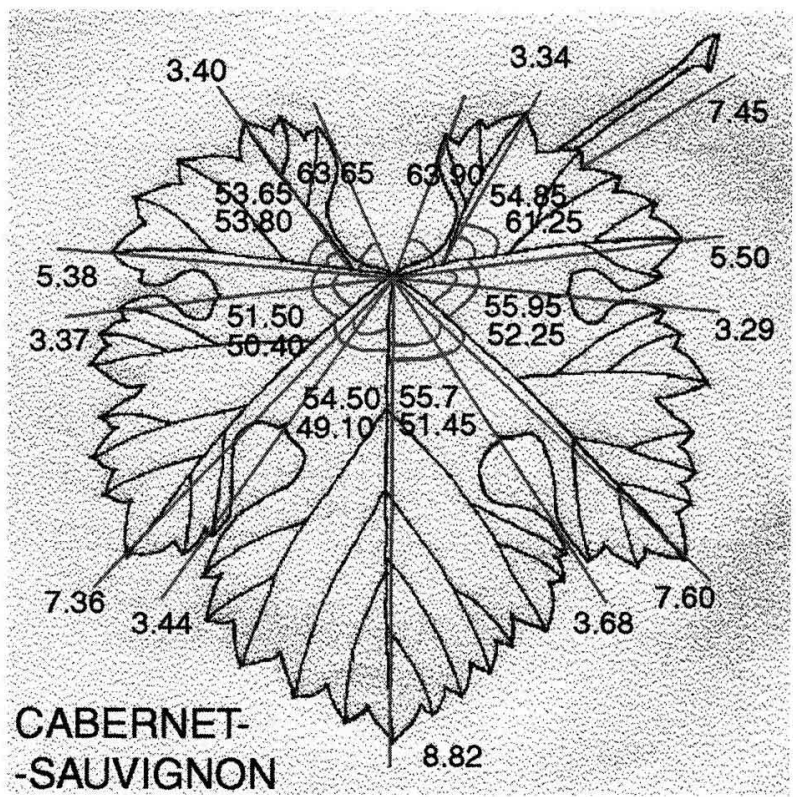

Figure 6. Average leaf of the Cabernet-Sauvignon variety (length in $\mathrm{cm}$, on the outside of the picture; angles in degrees, on the inside of the picture). 


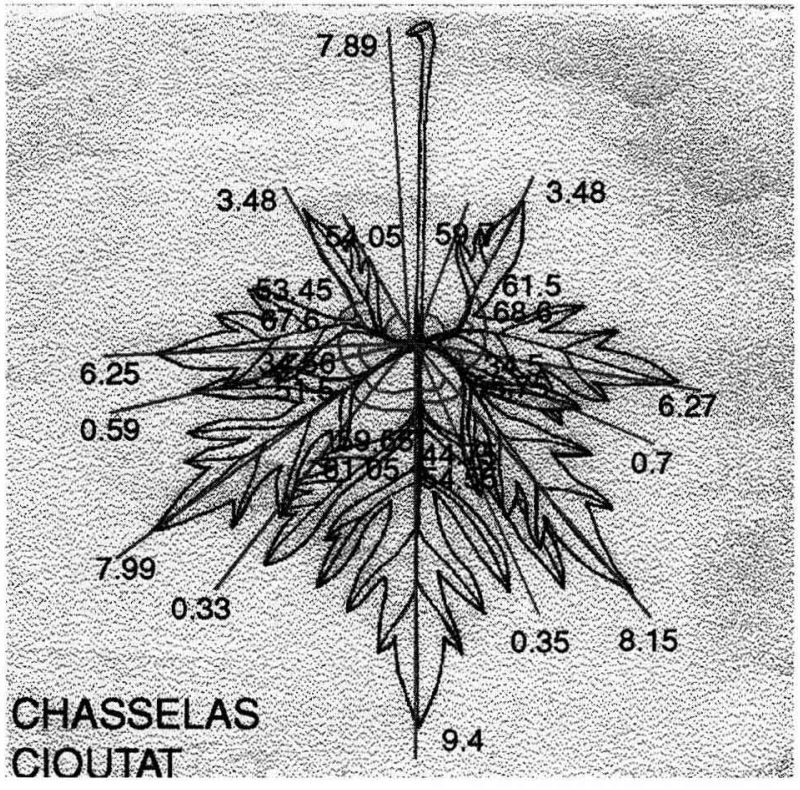

Figure 7. Average leaf of the Chasselas Cioutat variety (length in $\mathrm{cm}$, on the outside of the picture; angles in degrees, on the inside of the picture).

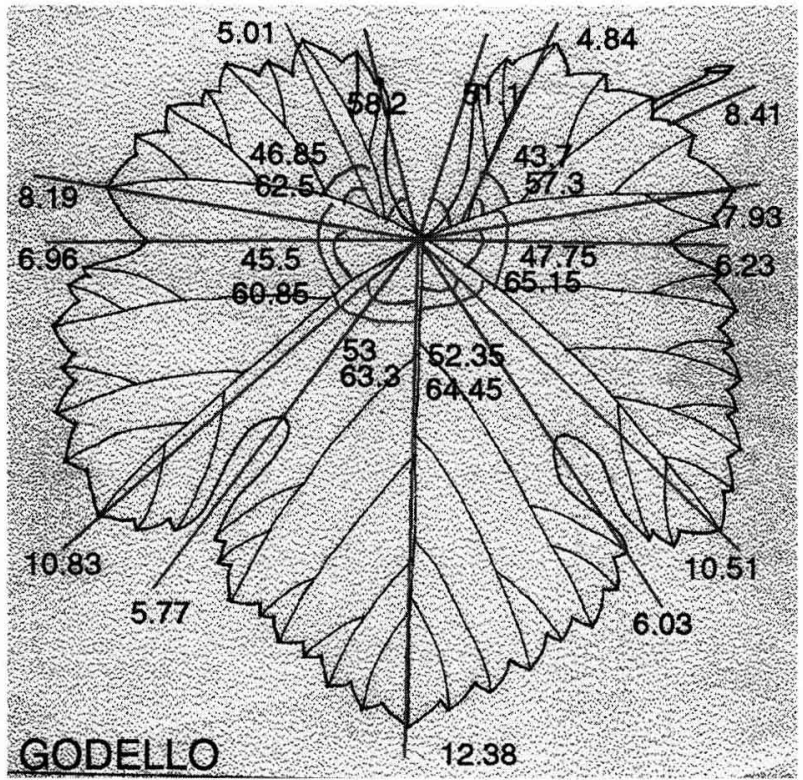

Figure 8. Average leaf of the Godello variety (length in $\mathrm{cm}$, on the outside of the picture; angles in degrees, on the inside of the picture).

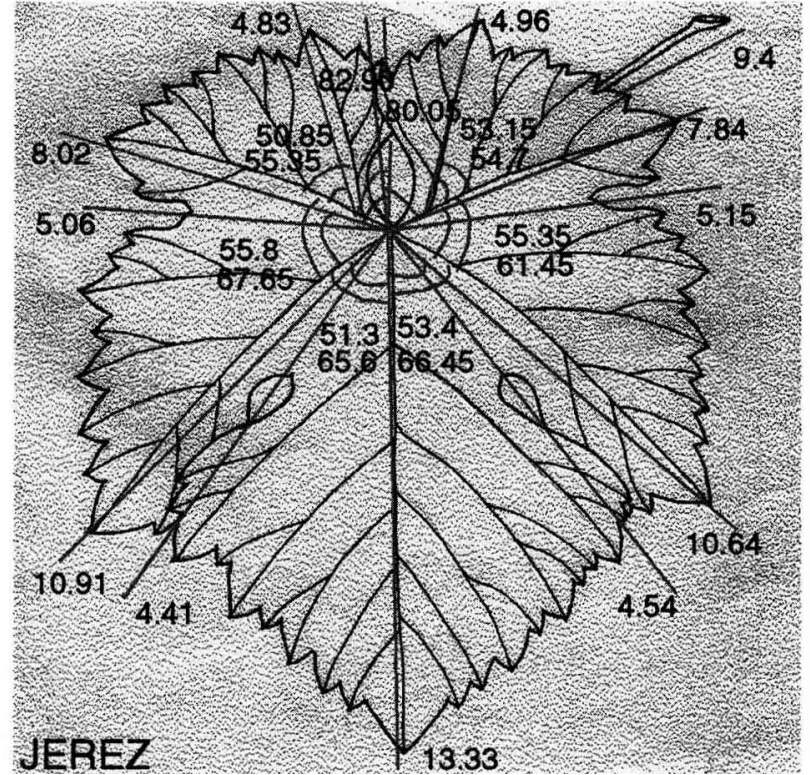

Figure 9. Average leaf of the Jerez variety (length in $\mathrm{cm}$, on the outside of the picture; angles in degrees, on the inside of the picture).

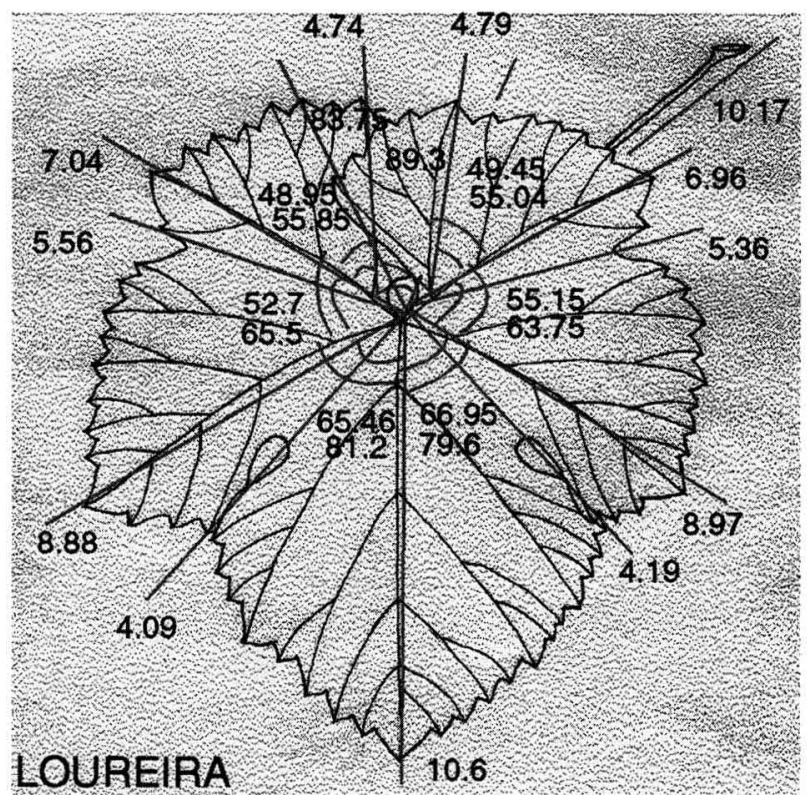

Figure 10. Average leaf of the Loureira variety (length in $\mathrm{cm}$, on the outside of the picture; angles in degrees, on the inside of the picture). 


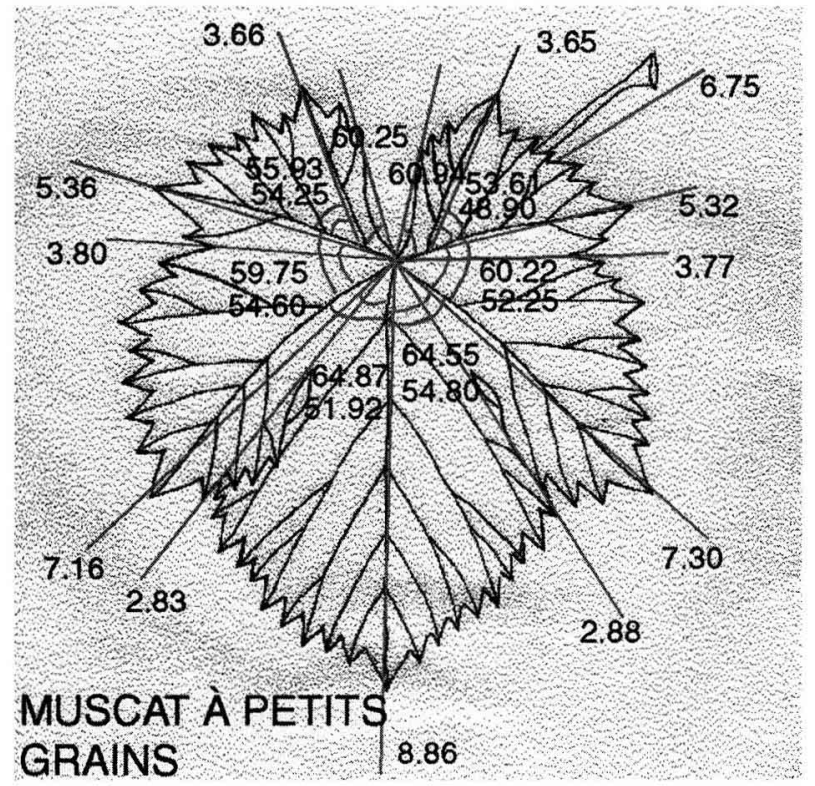

Figure 11. Average leaf of the Muscat à petits grains variety (length in $\mathrm{cm}$, on the outside of the picture; angles in degrees, on the inside of the picture).

Modern ampelography tries to elaborate more scientific methods by making use of different techniques: ampelometry, biometry but also enzymology and molecular biology. The main problem is that searching for reliable parameters which could identify different varieties may sometimes lead to the loss of the relation between the obtained results and the object of study. That is the reason why we consider that the method we propose is between these two points. In our method not only are the principles of classical ampelography and the methods of statistical analysis used, but also experience and personal observation. Rodrigues' work [31] has been our reference for the shaping of the average leaf and the numeration of teeth, Ravaz [25] and present-day ampelography for the measurements of length, the angles and statistical analysis and the OIV [23] for the study of qualitative features.

The reconstruction of the average leaf is made following consecutive steps and we consider that once it is put into practice it may quickly become
Table IV. Steps for the construction of the leaf.

\begin{tabular}{|c|c|}
\hline Step & Using instructions \\
\hline 1 & Tracing of the symmetry axis of the leaf. \\
\hline 2 & Placing of angles $\mathrm{A}, \mathrm{A}^{\prime}, \mathrm{a}, \mathrm{a}^{\prime}$ \\
\hline 3 & Placing of angles $\mathrm{B}, \mathrm{B}^{\prime}, \mathrm{b}, \mathrm{b}^{\prime}$ \\
\hline 4 & Placing of angles $\mathrm{G}, \mathrm{G}^{\prime}, \mathrm{g}, \mathrm{g}$ ' \\
\hline 5 & Placing of angles $\mathrm{D}, \mathrm{D}$ \\
\hline 6 & Delimitation of the seven main veins. \\
\hline 7 & Positioning of the lateral sinuses' base. \\
\hline 8 & $\begin{array}{l}\text { Tracing of the shape of lateral sinuses } \\
\text { and of the shape of teeth associated } \\
\text { with main veins. }\end{array}$ \\
\hline 9 & Tracing of the leaf blade perimeter. \\
\hline 10 & Deleting of the construction lines. \\
\hline 11 & Tracing of secondary and tertiary veins. \\
\hline 12 & $\begin{array}{l}\text { Finalisation of the drawing with china ink } \\
\text { pens of various sizes. }\end{array}$ \\
\hline 13 & Scanning of the average leaf drawing. \\
\hline
\end{tabular}

mechanical. The collection of data regarding the different parameters is the longer stage in the process. For each of them: teeth, sinuses and veins we have established categories. These categories are not restrictive but they are mere examples and may be modulated depending on the variety. Therefore, intermediate categories may be created with the aim of being as close to reality as possible. The value of this method lies in the fact that it does not impose a rigid system.

The flexibility to take decisions during the elaboration of the process makes it possible to obtain easily an average leaf.

We think the final pictures of the average leaf (figures $4-11$ ) presented in this work are so close to reality that even laymen would be able to associate each drawing with the corresponding live vine of each variety. For an expert who knows some of these varieties, it will be easy to identify them by only observing the final picture. Not only can this method verify whether the average leaf of each variety presents sinuses with different degrees of depth, but it also provides a final picture which makes it possible to assign two leaves with the same sinus depth index to one variety or another. 
This is because in the final picture not only are the vein length and angle and the distance from the petiolar point to the sinus base reflected, but also other characters such as the number of teeth, their shape, sinus shape and vein curvature, which contribute greatly to giving the typical shape to the leaves of each variety.

At the moment we have finished the reconstruction of the average leaf of 60 varieties in Galicia and Asturias (Spain) [21,24] and of different somaclones from Grenache $N$ cultivar $[18,19]$ and the results are highly satisfactory. This means that by simply examining the drawing of the average leaf of a given variety (established from pressed leaves and stored in a herbarium) the leaves of the field variety can be identified. With this method, we also have the advantage of using many of the parameters employed by other authors with different methods of leaf ampelographic descriptions $[1,5,9,32]$; this allows the comparison of our leaves with those studied by these authors. In addition, all the quantitative parameters used in our method are susceptible to being submitted to different types of statistical analyses (principal components, ANOVA, disciminant analysis, etc.). However, it is clear that before proposing the standardisation of the method, it will have to be tested on many other varieties. In this paper we practised our method on varieties of entire leaves (Albariño, figure 4), on divided leaves (Cabernet-Sauvignon, figure 6) and on very divided leaves (Chasselas Cioutat, figure 7). We consider that the eight varieties tested are a good sample of the foliar variability of the varieties of Vitis vinifera. These first results encourage us to continue testing other varieties to standarise the method.

We are equally conscious that the outcome of the method depends on the way the sampling is carried out. In order to have a representative homogeneous sample we have two possibilities:

a) to collect the leaves between the 8th and 12th nodes of the shoot, which according to several authors $[3,13,31]$ are those that for a given variety keep a relatively constant morphology;

b) to collect the leaves always from the same node (8th or 9 th).
In both cases it should be verified that the axillary bud is always placed on the same side so that all the leaves show their small side in the same position.

Before proving the validity of the generalisation of the method, we are conscious that certain faults in our protocol could already be corrected. First, we are dealing with an average leaf and it is not always easy to establish the mean of a qualitative feature. There is the risk of subjectivity in the appreciation of the shapes. However, regarding the morphology of teeth and the bases of sinuses more than two shapes seldom coexist.

It should be taken into account that the graphic representation is made starting from a series of average values. Accordingly, the result is often a symmetric leaf that does not unavoidably show the asymmetry that generally appears on a leaf in situ $[3,25,30]$. The shape of the leaf depends on the ontogenic mechanisms that control the cellular proliferation in such a way that normally the blade is smaller than the side corresponding to the location of the anticipated bud $[3,25]$. The leaf has consequently a large side and a small one which are located alternatively to the left and to the right, so that the impression of asymmetry oriented with preference to one side is avoided.

Thus, in order to reflect the natural asymmetry of the leaves in the sample, it would be better to calculate the means of measures on the two halves of leaves and reconstitute the whole leaf from the mean on the right side and the left side. Under these conditions the representation of a whole asymmetric leaf would be an improvement with respect to the schematic representation of Costacurta and Zambon [9], where only half of the leaf appears.

At the level of the veins, as Ravaz [25] points out, the main veins constitute the skeleton of the leaf and they form constant angles whose value is one of the more relevant characteristics of a given variety. On the contrary, the level of insertion of the opposite secondary veins is often displaced and the importance of this displacement varies along a vein to become almost null and void in the petiolar area [34]. The simple reading of table III does not 
account for this variation. An improvement of the method would consist in measuring the distance between the petiolar point and the bifurcation point of each of the secondary veins at the left and at the right side.

We think that the next improvement would be the computerisation of the complete method, not only the quantitative measures, but also the qualitative measures, the colour, and, most important of all, the reconstruction of the leaf from the mean values of the measured parameters. In fact, the modern techniques of analysis of images by means of computing, widely used in others disciplines, such as medicine, architecture, restoration of works of art and industrial design, could be successfully applied to ampelography. This would enable the graphic reconstruction of the average leaf of the varieties. From this point of view our method could be used as a database to put into practice these techniques. But an agreement on such a point is submitted to the possibility of establishing collaboration between ampelographic and computer researchers. At this moment, such collaboration does not exist.

However, before working on such a system, our method, which does not replace traditional techniques of varietal identification, may be reasonably considered to be an outstanding contribution to the study of the behaviour of a variety subjected to different agronomic factors.

\section{References}

[1] Boursiquot J.M., Faber M.P., Blachier O., Truel P., Utilisation par l'informatique et traitement statistique d'un fichier ampélographique, Agronomie 7 (1987) 13-20.

[2] Boursiquot J.M, Vignau L., Boulet J.C., Ricerche sull'utilizzazione dell'ampelometria, Riv. Vitic. Enol. 1 (1989) 37-52.

[3] Branas J., Viticulture, Déhan, Montpellier, 1974

[4] Carneiro L.C., Lima M.B., Ampelographic characterization of grapevine varieties using leaf shape, Ciênc. Téc. Vitivin. 6 (1987) 67-78.
[5] Cid-Alvarez N., Boursiquot J.M., Saa-Otero P., Romaní-Martínez L., Différenciation des cépages autochtones du Nord-Ouest de l'Espagne (Galice) et élaboration d'une clé de détermination basée sur l'ampélométrie, J. Int. Sci. Vigne Vin. 28 (1994) 1-17.

[6] Clemente S. de R., Ensayo sobre las variedades de la vid común que vegetan en Andalucia, Madrid, 1807.

[7] Clemente S. de R., Ensayo sobre las variedades de la vid común que vegetan en Andalucia, Ilustrada, Madrid, 1879.

[8] Costacurta A., Calò A., Carraro R. Giust M., Lorenzoni C., Essais d'identification variétale par des procédures de discrimination pas à pas, Abstract VII Symposium International sur la génétique et l'Amélioration de la vigne, Montpellier, 6-10 July, 1998.

[9] Costacurta A., Zambon F., Il computer per la ricerca ampelografica (nota metodológica), Riv. Vitic. Enol. 11 (1988) 473-477.

[10] De Michelis L., Maines F., Iacono F., Campostrini F., Analisi ampelografica in vite: la tecnica fillometrica quale ausilio per la caratterizzazione e il riconoscimento, Riv. Vitic. Enol. 3 (1997) 37-54.

[11] Dettweiler E., Preliminary Minimal Descriptor List of Grapevine varieties, Bundesalstalt für Züchtungsforschun um weim-und Gartenbau, Institut für Rebenzüchtung Geilweilerhof, Siebeldingen, 1991.

[12] Eiras-Dias J.E.J., Analise odontomètrica de uma casta em anos sucessivos, Ciênc. Téc. Vitivin. 2 (1983) 39- 48 .

[13] Galet P., Cépages et vignobles de France, tome I, Déhan, Montpellier, 1956.

[14] Galet P., Précis d'ampélographie pratique, 5 ed., Déhan, Montpellier, 1985.

[15] Galet P., Cépages et vignobles de France, vol. I, Les vignes américaines, Déhan, Montpellier, 1988.

[16] Galet P., Cépages et vignobles de France, vol. II. L'ampélographie française, Déhan, Montpellier, 1990.

[17] Goethe M., Handbuch der Ampelographie, Graz, Commission-Verlag von Leykam-Josefsthal, 1878.

[18] Martínez M.C., Boursiquot J.M., Grenan S., Boidron R., Étude ampelométrique de feuilles adultes de somaclones du cv. Grenache N (Vitis vinifera L.), Can. J. Bot. 75 (1997) 333-345.

[19] Martínez M.C., Grenan S., Boursiquot J.M., Variabilidad de algunos caracteres ampelográficos y de producción, en somaclones del cultivar Grenache N (Vitis vinifera L.), Acta Hortic. 18 (1997) 271-280. 
[20] Martínez M.C., Loureiro M.D., Mantilla J.L.G. Importancia y validez de distintos parámetros ampelométricos de hoja adulta para la diferenciación de cepas de Vitis vinifera L., de distintos cultivares, Invest. Agr. Prod. Prot. Veg. 9 ( 1995) 377-389.

[21] Martínez M.C., Pérez J.E., La vid en el occidente del Principado de Asturias. Descripción ampelográfica de las variedades, Servicio de Publicaciones del C.S.I.C., Madrid, 1998.

[22] Martínez de Toda F., Sancha J.C., Caractérisation ampélographique des cultivars rouges de Vitis vinifera L. conservés en Rioja, Bull. O.I.V., no. 793-79, 1997, pp. 221-234.

[23] Office International de la Vigne et du Vin (O.I.V.), Le code des caractères descriptifs des variétés et espèces de Vitis, Dedon, Paris, 1983.

[24] Pérez J.E., Martínez M.C., Réprésentation morphologique de la feuille moyenne de quarante variétés de Vitis vinifera L., cultivées en Galice, Abstract VII Symposium International sur la génetique et l'Amélioration de la vigne, Montpellier 6-10 July, 1998.

[25] Ravaz L., Les vignes américaines. Porte-greffe et producteurs directs, Coulet et fils, Montpellier, 1902.

[26] Rodrigues A., Sôbre a caracterizaçao das espécies e hibridos do género Vitis, Agron. Lusitana 1 (1939) 315-326.
[27] Rodrigues A., Variaçoes do recorte da fôlha da videira, Agron. Lusitana 3 (1941) 189-193.

[28] Rodrigues A., Acêrca do valor taxonomico do numero de dentes da fôlha na separaçao de dois hibridos do genero Vitis L., Agron. Lusitana 3 (1941) 325-340.

[29] Rodrigues A., O polimorfismo foliar e os estudos de filometria. Aplicaçao prática de um metodo ampelometrico, Agron. Lusitana 4 (1942) 339-359.

[30] Rodrigues A., Sôbre o recorte e assimetria da fôlha da videira, Agron. Lusitana 4 (1942) 137-153.

[31] Rodrigues A., Um metodo filométrico de caracterizaçao. Fundamentos. Descripçao-Técnica Operatôria, Serviço editorial da repartiçao de estudos, informaçao e propaganda, Lisboa, 1952.

[32] Schneider A., Grape variety identification by means of ampelographic and biometric descriptors, Riv. Vitic. Enol. 1 (1996) 11-16.

[33] Schneider A., Zeppa G., Biometria in ampelografia: l'uso di una tavoletta grafica per effetuare rapidamente misure filometriche, Vignevini 9 (1988) 37-40.

[34] Viala P., Vermorel, V. Ampélographie, tomes 1-7, Masson et Cie, Paris, 1901-1910. 